DEPÓSITO LEGAL ZU2020000153

Esta publicación científica en formato digital

es continuidad de la revista impresa

ISSN 0041-8811

E-ISSN 2665-0428

Revista

de la

Universidad

del Tunlia

Fundada en 1947

por el Dr. Jesús Emrique Lossada

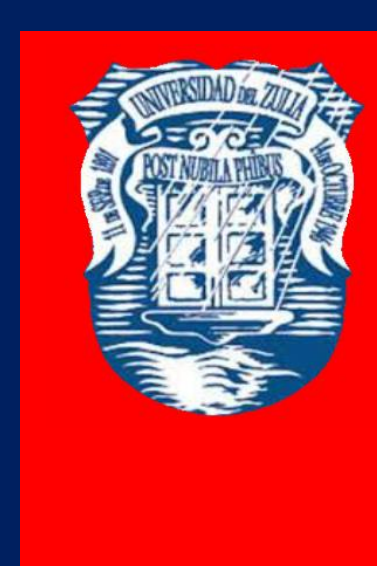

Ciencias

Sociales

y Arte

Aกัต 11 No 31

Septiembre - Diciembre 2021

Tercera ípoca

Maracailbo-Venezuela 


\title{
Methods of calculating the efficiency of clusters and possible modalities for their development
}

\author{
Nataliia Lytvynenko * \\ Maryna Khmara ** \\ Nataliia Rylach *** \\ Olga Spektor **** \\ Serhii Orekhov *****
}

\begin{abstract}
The objective of the article is to analyze the method of calculating the efficiency of high-tech clusters and alternative models of their development. Method. The methodological basis of the study is a series of general and specific cognition methods. In the research process, the following were used: the formal-logical method, the system and the structural, comparative-legal, logical-legal and other scientific research methods. Results of the investigation. Four groups of efficiency indicators of the organizational and economic regulation mechanism of the administrative activity of a business cluster are defined. The difference between traditional industrial clusters and innovation clusters is considered. Examples of successful cluster operation in some countries around the world are studied. Practical meaning. It is emphasized that the efficiency of the cluster, and therefore its development, is significantly influenced by the availability of scientific potential and activity of research institutes, as well as access to non-reimbursable funds (institutions, agencies) and the operation of technology parks. Value / originality. It is observed that due to globalization, the role of clusters in competition is increasingly important. In this context, the forms of cluster development in Ukraine were proposed, as well as examples of successful clusters in Ukraine were considered.
\end{abstract}

KEY WORDS: cluster, industrial cluster, innovation cluster, technology parks, grant funds, research institutes, competitiveness, development.

${ }^{*} \mathrm{PhD}$ in Economics, Associate Professor of the Department of International Communication of Institute of International Relations of Taras Shevchenko National University of Kyiv University. Email: office@iir.kiev.ua, ORCID ID: https://orcid.org/0000-0002-3030-3315

** PhD in Economics, Associate Professor of the Department of International Business of Institute of International Relations of Taras Shevchenko National University of Kyiv University, ORCID ID: https://orcid.org/0000-0002-1205-2428

*** PhD in Economics, Senior Researcher of Institute of International Relations of Taras Shevchenko National University of Kyiv University, ORCID ID: https:/orcid.org/0000-0002-7200-3978

**** PhD in Law, Professor of the Department of International Law and Comparative Law of Kyiv International University, ORCID ID: https://orcid.org/0000-0003-3033-889X

***** Doctor of Legal Sciences, Professor of the Department of International Law and Comparative Law of Kyiv International University, ORCID ID: https://orcid.org/0000-0002-8388-0140 
REVISTA DE LA UNIVERSIDAD DEL ZULIA. 3ㄹ época. Año 11 N 31, 2020

Nataliia Lytvynenko et al.///Methods of calculating the efficiency of clusters ...97-118

DOI: http://dx.doi.org/10.46925//rdluz.31.08

\section{Método de cálculo de la eficiencia de los clusters y posibles modalidades para su desarrollo}

RESUMEN

El objetivo del artículo es analizar el método de cálculo de la eficiencia de los clusters de alta tecnología y modelos alternativos de su desarrollo. Método. La base metodológica del estudio es una serie de métodos de cognición generales y específicos. En el proceso de investigación se utilizaron: el método formal-lógico, el sistema y los métodos de investigación científica estructural, comparativo-legal, lógico-legal y otros. Resultados de la investigacion. Se definen cuatro grupos de indicadores de eficiencia del mecanismo organizativo y económico de regulación de la actividad administrativa de un clúster empresarial. Se considera la diferencia entre los clústeres industriales tradicionales y los clústeres de innovación. Se estudian ejemplos de funcionamiento exitoso de clústeres en algunos países del mundo. Significado práctico. Se enfatiza que la eficiencia del clúster, y por ende su desarrollo, está significativamente influenciado por la disponibilidad de potencial científico y actividad de los institutos de investigación, así como el acceso a fondos no reembolsables (instituciones, agencias) y la operación de parques tecnológicos. Valor / originalidad. Se observa que debido a la globalización, el papel de los clústeres en la competencia es cada vez más importante. En este contexto, se propusieron las formas de desarrollo de clústeres en Ucrania, así como se consideraron ejemplos de clústeres exitosos en Ucrania.

PALABRAS CLAVE: cluster, cluster industrial, cluster de innovación, parques tecnológicos, fondos de subvenciones, institutos de investigación, competitividad, desarrollo.

\section{Introduction}

Over the past 15 - 20 years, the cluster approach in shaping industrial and economic policies is becoming increasingly popular in the world. Great Britain, the USA, India, France, Italy, Denmark, Germany and Canada are considered the most clusterized countries in the world. The relevance of this topic for Ukraine is very significant, since the cluster approach in Ukraine is advancing and developing very slowly, while the global economy is actively integrating it into its industrial policy. The emergence of high-tech clusters is preconditioned by globalization trends in the global economy.

A cluster is a voluntary, industry- and territory-specific association of business structures that work closely with scientific (educational) institutions, public organizations 
REVISTA DE LA UNIVERSIDAD DEL ZULIA. $3^{a}$ época. Año 11 N 31, 2020

Nataliia Lytvynenko et al.///Methods of calculating the efficiency of clusters ...97-118

DOI: http://dx.doi.org/10.46925//rdluz.31.08

and local authorities in order to increase the competitiveness of their own products and promote the economic development of the region.

A high-tech cluster is a unique combination of firms and organizations that are informatively and technologically interconnected and geographically localized. Their activities are aimed at expanding the technical and technological capacities of their members and raising the level of economic development of priority industry branches. The development of high-tech industrial clusters that are capable of intensifying innovation activity is well-known in the world as a means of advancing regions of a country to becoming innovative, developed territorial systems. The mechanisms of cluster policy aimed at enhancing industrial innovation potential are actively used by many developed countries of the world.

So the purpose of the paper is to analyze the method of calculating the efficiency of high-tech clusters and to propose the possible modalities for their development.

The effective functioning of a cluster association and its structural units depends largely on whether correct methods of management have been chosen, and their combination and coherence, based on how advanced the institutional environment is, forms of ownership, specifics of tasks and other factors.

To assess management efficiency, it is advisable to use both concepts of "efficiency" and "productivity" of labour. The concept of productivity may be used to characterize the labour performance of management personnel. The principle of determining labour performance is the same in calculating both productivity and efficiency of labour, that is, it consists in correlating the results with labour costs. The differences lie only in the scale and content of specific indicators of costs and results of labour (Popov 1976). However, at the present stage of economic development, it is quite difficult to give a direct assessment of management efficiency in a cluster due to the lack of elaboration of many issues in this area, both theoretically and practically. Primarily, the complexity of evaluating management efficiency lies in the difficulty of determining the contribution of management staff to the output of the business cluster, which is the consequence of activities of each member of the association, as well as the influence of a number of external, in relation to the cluster, conditions and factors. As a result, several approaches of different authors to the assessment of management efficiency can be singled out. 
REVISTA DE LA UNIVERSIDAD DEL ZULIA. 3e época. Año 11 N³1, 2020

\section{Metholodgy}

To solve the tasks set in the Article the following general and special methods were used:

the method of scientific abstraction, as well as the methods of induction and deduction, analysis and synthesis method were used in the study of the essence of the cluster, its features, clarification of the concepts of "industrial cluster", "innovative cluster", "efficiency" and "productivity", the formulation of methodological principles the basis for building a study of financial capital of clusters;

functional and system analysis method was applied when highlighting the features and patterns of formation and functioning of the cluster;

with the help of historical method the process of transformation of the cluster approach over the past years was investigated;

the method of comparative analysis was used in the study of practice of applying cluster approach in some counties of the world and in certain Ukrainian cities;

the method of systematization and generalization helped in the study of world and domestic experience in the formation and operation of clusters;

graphical method was applied to visualize the groups of the efficiency indicators for the organizational and economic mechanism of regulating management activity of a business cluster, as well as the number of clusters in the economies of the leading countries;

the method of economic and statistical analysis helped to identify the most effective ways to develop clusters in the economy of Ukraine.

\section{Literature Review}

The issue of calculating clusters' efficiency is rather widely discussed. In particular, Tapas Kanungo et al (2002) analyzed k-means clustering algorithm and proposed the most simple and efficient implementation of this algorithm, which was called the filtering algorithm.

Kristina Razminienè et al (2016) verified the validity of cluster efficiency measurement tool through literature analysis and case study. This tool allows not only to 
REVISTA DE LA UNIVERSIDAD DEL ZULIA. 3ㄹ época. Año 11 N 31, 2020 Nataliia Lytvynenko et al.///Methods of calculating the efficiency of clusters ...97-118 DOI: http://dx.doi.org/10.46925//rdluz.31.08

measure efficiency in comparison to other clusters, but also to give valuable observation of how the performance of a cluster can be improved.

Channamma Patil \& Ishwar Baidari (2019) proposed a new method called depth difference (DeD) for estimating the optimal number of clusters in a dataset based on data depth, which is comparatively simple and efficient.

The issue under consideration was also investigated by Tetiana Boyko (2011), Iryna Horodova (2012), Mykola Kiryk (2014), Vorozhbit et al (2018), Gorbunov et al (2018), Novikov, S., \& Prosvirina, N. (2019), Danilov et al (2020), Prokhorova et al (2020), and many others.

3. Results and Discussion

The current organizational and economic mechanism for managing such an association, as a cluster, should contribute to the accomplishment of tasks, set for achieving the goal of the activity, and obtaining an economic effect with minimal labour, a material and monetary cost, that is, ensuring a high efficiency of management. It is an integral part of the overall problem of increasing the economic efficiency of the cluster's activities.

Having summarized the current experience in evaluating the efficiency of management activity of an entity, we consider it appropriate to combine into four groups the efficiency indicators for the organizational and economic mechanism of regulating management activity of a business cluster (Table 1) (Schwab 2014).

During the reporting period, the profitability of economic activity must have an upward trend, which is indicative of an effective functioning process of the organizational and economic mechanism of management regulation by each member of the cluster association. Profitability of the business cluster's management (R) can be calculated by using the formula:

$$
\text { Rу.д.кл. }=\frac{\sum_{i=1}^{n} \text { оП }}{\sum_{i=1}^{n} B y} \text {, }
$$


REVISTA DE LA UNIVERSIDAD DEL ZULIA. $3^{a}$ época. Año 11 N 31, 2020

Nataliia Lytvynenko et al.///Methods of calculating the efficiency of clusters ...97-118

DOI: http://dx.doi.org/10.46925//rdluz.31.08

Table 1.

\begin{tabular}{|c|c|c|}
\hline Group & Name of group & Set of indicators \\
\hline \multirow[t]{3}{*}{1} & \multirow[t]{3}{*}{ Organizational assessment } & Provision of job descriptions \\
\hline & & $\begin{array}{l}\text { Provision of orders and agreements } \\
\text { on delimitation and delegation of authority }\end{array}$ \\
\hline & & $\begin{array}{l}\text { Qualitative assessment of the } \\
\text { structure of the cluster's management } \\
\text { apparatus and conformity of their } \\
\text { professional skills with certain } \\
\text { requirements }\end{array}$ \\
\hline \multirow[t]{5}{*}{2} & \multirow[t]{5}{*}{ Performance results } & Net profit of each member \\
\hline & & $\begin{array}{l}\text { Each member's production } \\
\text { profitability } \\
\text { Profitability of the management } \\
\text { activities of the cluster }\end{array}$ \\
\hline & & $\begin{array}{c}\text { Profitability of the cluster's } \\
\text { management activity }\end{array}$ \\
\hline & & $\begin{array}{l}\text { Profitability of each participant's } \\
\text { management activity against optimal } \\
\text { management costs }\end{array}$ \\
\hline & & $\begin{array}{l}\text { Profitability of each participant's } \\
\text { management activity against actual } \\
\text { management costs }\end{array}$ \\
\hline \multirow[t]{3}{*}{3} & \multirow{3}{*}{$\begin{array}{l}\text { Cost-effectiveness of the } \\
\text { organizational and economic } \\
\text { mechanism of management activity } \\
\text { regulation }\end{array}$} & $\begin{array}{l}\text { Percentage of management costs to } \\
\text { the cluster's total costs }\end{array}$ \\
\hline & & $\begin{array}{l}\text { Absolute deviation of actual } \\
\text { management costs of each member from the } \\
\text { optimal costs }\end{array}$ \\
\hline & & $\begin{array}{l}\text { Percentage of labour expenses for } \\
\text { cluster's management personnel to the total } \\
\text { amount of labour costs }\end{array}$ \\
\hline \multirow[t]{4}{*}{4} & \multirow[t]{4}{*}{ Functional evaluation } & $\begin{array}{l}\text { The degree of execution of approved } \\
\text { plans, budget and certain tasks }\end{array}$ \\
\hline & & $\begin{array}{l}\text { Provision of acknowledgements or } \\
\text { reprimands for the performance of official } \\
\text { duties, including in monetary terms }\end{array}$ \\
\hline & & $\begin{array}{l}\text { Punitive sanctions and monetary } \\
\text { claims by external contractors of financial } \\
\text { and economic activity }\end{array}$ \\
\hline & & $\begin{array}{l}\text { Punitive sanctions and monetary } \\
\text { claims due to an untimely provision of } \\
\text { financial or management statements }\end{array}$ \\
\hline
\end{tabular}


REVISTA DE LA UNIVERSIDAD DEL ZULIA. 3época. Año 11 N 31, 2020

Nataliia Lytvynenko et al.///Methods of calculating the efficiency of clusters ...97-118

DOI: http://dx.doi.org/10.46925//rdluz.31.08

The upward trend of this indicator illustrates effective management regulation of the cluster association.

The purpose of a company that manages regional innovation system is to launch and develop new forms of entrepreneurship in accordance with the interests of the regional education system, an educational institution that promotes the creation of small innovative enterprises, other stakeholders of the regional innovation system, etc. The efficient result of this model is the flow of new projects related to the formation of new business structures owners of individual business processes within the closed innovation cycle.

The model of managing innovation processes in the region is an alternative to the cluster model. It is a regional innovation system, the key elements of which are start-ups (technology parks, research centres, technology transfer centres, business incubators, common objects centres, etc.).

The idea of increasing the competitiveness of the national economy by implementing cluster strategies is not new. Nevertheless, at the stage of economic recovery, when traditional methods of diversification can no longer give proper returns, the use of a cluster business organization model as an adequate tool for modernizing the economy has no alternative. The interdependence and interconnection between clustering processes, increasing competitiveness and accelerating innovation is a new economic phenomenon that can withstand the onslaught of global competition and adequately meet the requirements of national and regional development (Lienchuk \& Vlaskin 2010).

In his first address to the American Congress, President Barack Obama, while noting the importance of implementing an innovative strategy for the nation's prosperity, pointed to the need to support dynamic interaction between large and small companies, universities, and financial institutions on the back of cluster strategies that are being implemented, first and foremost, on regional level, and that can provide the dynamism for the country's economy as a whole.

Similar steps are also being made in EU countries, where cluster strategies are also seen as an essential tool for innovation in the region. "We need more world-class clusters in the EU," said Vice-President of the European Commission Günter Verheugen, who is responsible for entrepreneurial and industrial policy. 
REVISTA DE LA UNIVERSIDAD DEL ZULIA. $3^{a}$ época. Año 11 N 31, 2020

Nataliia Lytvynenko et al.///Methods of calculating the efficiency of clusters ...97-118

DOI: http://dx.doi.org/10.46925//rdluz.31.08

Cluster approach is, above of all, a new management technology that can enhance the competitiveness of a single region or industry, and the country as a whole (Lienchuk \& Vlaskin 2010).

International practice shows that in the last two decades the process of cluster formation has been very active. In general, according to experts, to date clustering has covered about $50 \%$ of the economies of the leading countries of the world (table 2):

Table 2.

\begin{tabular}{|c|c|}
\hline Country & Number of clusters \\
\hline Great Britain & 168 \\
\hline Germany & 32 \\
\hline Denmark & 34 \\
\hline Italy & 206 \\
\hline India & 106 \\
\hline Netherlands & 20 \\
\hline USA & 380 \\
\hline France & 96 \\
\hline Finland & 9 \\
\hline
\end{tabular}

In the US, over half of business work within clusters, and the share of GDP produced within them has exceeded $60 \%$. There are over 2,000 clusters in the EU, employing $38 \%$ of its workforce (Kiryk 2014).

Danish, Finnish, Norwegian and Swedish industries are fully covered by clustering. Finland, whose economic policy is based on it, has been leading in global competitiveness ratings in the 2000s. Due to high productivity clusters, this country, having only $0.5 \%$ of the world's forest resources, provides $10 \%$ of the world's exports of wood products and $25 \%$ - of paper. In the telecommunications market, it provides 30\% of the world's mobile communications equipment exports and 40\% of mobile phones (Lienchuk \& Vlaskin 2010).

Increasing competitiveness through cluster initiatives is becoming a core element of the strategies for the vast majority of countries. The analysis of over 500 cluster initiatives that have been implemented over the past 10 years in 20 countries shows that the high 
REVISTA DE LA UNIVERSIDAD DEL ZULIA. $3^{a}$ época. Año 11 N³1, 2020

Nataliia Lytvynenko et al.///Methods of calculating the efficiency of clusters ...97-118

DOI: http://dx.doi.org/10.46925//rdluz.31.08

competitiveness of these countries is due to the strong positions of individual clusters - the driving forces of competitiveness.

Indeed, as we can see from the global experience of the functioning of the most prosperous economic systems, high competitiveness and stable economic growth are ensured, primarily, by factors stimulating the spread of new technologies. Given this, modern competitive advantages are almost entirely determined by the advantages in production technologies, management, the organization of product promotion, and the successful development of the economic system's competitiveness is possible with the integrated use of cluster mechanism theories and modern concepts of innovation development. In this regard, many countries - both economically developed and those that are just developing their market economies, are increasingly using a cluster approach in support of the most promising directions and forms of entrepreneurship, in the formation and regulation of national innovation systems.

Unlike traditional industrial clusters, innovative clusters represent a system of close interactions not only between firms, their suppliers and clients, but also knowledge institutes, which include large research centres and universities. Acting as generators of new knowledge and innovations, they provide a high level of education in the region. It then becomes possible to coordinate efforts and financial resources for the creation of a new product and technologies and their entry into the market. In fact, it becomes possible to build a closed technology chain within the cluster - from product creation to production and market entry.

It should be noted that there is another distinction between innovative clusters and traditional industrial clusters, which is determined by the creation of mainly export-oriented products and technologies within their framework, which means that intra-cluster competitive advantages become significant on an international scale (Kiryk 2014).

The formation of a special infrastructure plays an important role in the implementation of state support for the development of clusters abroad. Typically, the implementation of cluster strategies involves the presence of grant-making funds (institutions, agencies) supporting cluster initiatives: for example, DATAR -the National Agency for Planning (France), CASSIS - Cluster Search and Classification Information System (Luxembourg), the National Competitiveness Council (USA), LINK Cooperation 
REVISTA DE LA UNIVERSIDAD DEL ZULIA. 3época. Año 11 N 31, 2020

Nataliia Lytvynenko et al.///Methods of calculating the efficiency of clusters ...97-118

DOI: http://dx.doi.org/10.46925//rdluz.31.08

Programme (UK). Furthermore, special institutes are established that can effectively perform functions of development, construction of network structures and their internationalization. These include centres of expertise (Finland), centres of excellence (USA), consulting, marketing, analytical and branding companies (Economic Competitiveness Group (USA), Centre for Marketing and Analytical Research (Kazakhstan), institutes and agencies within cluster initiatives (Technical University of Munich). An integral part of the infrastructural maintenance of cluster strategies is the creation of business incubators, technology parks, and special economic zones, that are, in fact, catalysts for the formation of industrial clusters (Lienchuk \& Vlaskin 2010).

Entry into the cluster enhances the status of companies, promotes increased attention to them by financial agencies, promotes the growth of their international reputation and brand popularity, attracts additional resources to the region. In turn, the cluster's presence enhances the role of regional administrations, as it develops and strengthens the economy of their region, stimulates economic growth and accelerates the solution of social problems, creates conditions for the successful development of less developed areas.

Therefore, as the world practice shows, central governments agencies that conduct a cluster policy "from the top", as well as regional authorities or local associations of entrepreneurs proposing the implementation of "bottom-up" cluster stimulation programmes, can act as initiators of cluster policy. Such programmes are called "cluster initiative", which is defined as an organized attempt to increase the growth rate and competitiveness of a cluster in a particular region, involving cluster firms, the state, and research institutes in the process.

Examples of the most successful developments of cluster initiatives in the European Union among old members include Austria (especially the cluster initiative in Upper Austria, where the term "cluster" has been effectively used as a "brand" to improve the image of the region and attract foreign direct investment into local enterprises), Great Britain (Scotland), Spain (Catalonia), Germany (North Rhine-Westphalia), while among Central and Eastern European countries, the public-private partnership in the development of cluster initiatives has been effective in Slovenia. As of now, 11 cluster initiatives have been selected for targeted financing on a competitive basis by the government of Slovenia, among which the most developed are three clusters: automotive, machine tool, and transport and logistics. 
REVISTA DE LA UNIVERSIDAD DEL ZULIA. $3^{a}$ época. Año 11 N 31, 2020

Nataliia Lytvynenko et al.///Methods of calculating the efficiency of clusters ...97-118

DOI: http://dx.doi.org/10.46925//rdluz.31.08

Thus, today many countries are developing state programmes and bear high financial costs for "cultivating" clusters. Such programs have been developed by practically all EU countries. They are implemented in line with the Lisbon Strategy, with the aim of introducing knowledge economy in the EU member states, which can provide such level of competitiveness on the basis of innovative clusters, that exceeds the rates of the US and Japanese economies.

In Germany, until recently, the development of regional clusters occurred without state intervention. However, since 2003, the government has been paying close attention to cluster initiatives, primarily concerning projects for the creation and development of clusters in the high-tech industry, where the state supports the consolidation of efforts by industry and research centres at the expense of not only local but also federal sources. The national government implements a large number of support programmes for individual regions and technology areas, yet a more specific plan for cluster development is carried out by local authorities, which allows for the specific features of each region to be taken into account. For example, a region like Ruhr, specializing in heavy industry, is trying to move on to information technology. Clusters, such as the Baden-Württemberg automotive industry, the medical device industry in Tuttlingen, the "chip region" around Dresden or the biotech cluster in the Berlin-Brandenburg region are successfully operating on this basis (Lienchuk $\&$ Vlaskin, 2010).

Understandably, many clusters are still small in size or have not achieved competitiveness and are in search of ways to get in the lead. The effectiveness of the cluster, and hence its development, is significantly influenced by the availability of scientific potential and the activity of research institutes. The state defines the scope of activity of the research institute, providing it with appropriate powers and equipment. In Bavaria, for example, there are specially appointed persons (coordinators) that organize the interaction of agents within the cluster. Coordinators are usually selected from the professorial environment. Germany has established close links between businesses and the academic environment. University professors are often also employed in research institutes, which in turn collaborate with private firms. Thus, research institutes, the purpose of which is to transfer technologies, maintain strong relations with both universities and the industrial 
REVISTA DE LA UNIVERSIDAD DEL ZULIA. $3^{a}$ época. Año 11 N 31, 2020

Nataliia Lytvynenko et al.///Methods of calculating the efficiency of clusters ...97-118

DOI: http://dx.doi.org/10.46925//rdluz.31.08

sector. Professors are allowed to set up private research centres, which are independent legal entities, on the university premises.

The German Federal Ministry of Education and Research provides support in the international exchange of knowledge and key innovations in such fields as health, biotechnology, information technology, ecology, and transport, as well as supports educational and research programmes abroad.

While until recently, clusters used to be a privilege for the most developed economies, in recent years this phenomenon has occurred in developing countries as well. In Hungary, Poland, the Czech Republic, and Slovenia clustering is backed by special programmes. In particular, by 2003, a system was established in Hungary with more than 150 clusters in the following areas: construction, textile manufacturing, thermal water, optical mechanics, automotive industry, wood industry, food industry, electronics, etc. Over 75 industrial parks are operating there, uniting 556 companies, with a total number of 60,000 employees. Hungarian industrial parks have substantial customs and tax exemptions. In 2005 - 2009, the state allocated 26 billion EUR specifically for the establishment of technological platforms and innovation clusters. On top of this, 80 million EUR were earmarked to strengthen relations between universities and the industry, 7 million EUR - to bolster small innovative businesses, and 50 million EUR - to expand the network of business incubators that give initial support to small businesses (Boyko 2011).

The success of technology parks in facilitating the transfer of technology and the attraction of clusters of highly innovative firms has motivated countries around the world, including the People's Republic of China, to promote regional development. Due to similarities between a planned economy and economies of other countries, which are transitioning to a market economy, the Chinese model of technology parks imitated other transition economies. However, despite its economic significance, such development was largely ignored in organizational research. This study explores a specific example of a sector cluster in China, the Beijing Zhongguancun Science Park (ZGC), the largest cluster of semiconductor, computer, and telecommunication companies in China, comprised of both domestically and foreign-invested firms.

Although the operations of science parks in Taiwan have long enjoyed governmental support, the proposed case study provides three energy policy implications. Firstly, a nation- 
REVISTA DE LA UNIVERSIDAD DEL ZULIA. 3época. Año 11 N 31, 2020

Nataliia Lytvynenko et al.///Methods of calculating the efficiency of clusters ...97-118

DOI: http://dx.doi.org/10.46925//rdluz.31.08

wide macro viewpoint is needed for the planning of high-technology industrial developments. When high-technology industries are considered as one of the national/regional economies by governmental agencies, the integrated energy-efficient economy index can better represent the contributions of the high-technology industries. Secondly, a proper industrial clustering mechanism can further help high-technology industries to reach the status of an energy-efficient economy. Government-supported joint environmental facilities, such as planned land and road usage, electricity and water supply, telecommunications system, sewerage system and wastewater treatments, can improve the energy efficiency of high-technology industries. Thirdly, the governmental policies on the taxing and management system in science parks would also have a direct impact on the degree of energy efficiency in an economy of high-technology industries. The proposed policy implications should lead to improved future research for better developments of science parks and high-tech industries. Technically, for other future research, more innovative and practical indices should be discovered and applied in the future, such that are in line with the integrated concept of economic and energy considerations for specific industry requirements.

Clusters mean long-term development. This approach requires a minimum of five to seven years. However, the world is yet to come up with a more effective approach to the economic development of an area, when it comes to attracting additional resources to a region.

Today, according to the 2016 report of the Ministry of Economic Development and Trade of Ukraine, there are 42 clusters registered on the territory of the country, specializing in information technology, engineering, agriculture, and energy. At the same time, the content analysis of information resources provides online representations of only 5 clusters, which is a vivid illustration of their actual work level.

How to start cluster development in Ukraine? First of all, it is about preparing a critical mass of managers for business, science, public sector, and local authorities, the ones who understand the phenomenon of a cluster, its advantages and disadvantages. Therefore, in the past three years, this topic has become an integral part of all MBA programmes at Ukrainian business schools. 
REVISTA DE LA UNIVERSIDAD DEL ZULIA. $3^{a}$ época. Año 11 N 31, 2020

Nataliia Lytvynenko et al.///Methods of calculating the efficiency of clusters ...97-118

DOI: http://dx.doi.org/10.46925//rdluz.31.08

However, understanding the phenomenon of a cluster, of course, is not enough. Professionals are required to take responsibility for creating clusters in the regions. And, most importantly, these clusters should not play the role of "exclusive clubs" for their members; rather become an effective engine of local economic transformation.

Less than a year ago representatives of Kharkiv-based small and medium businesses, universities working in the field of renewable energy and energy efficiency, authorities and local self-government bodies, united as the Kharkiv energy cluster.

Today, the Kharkiv energy cluster has an entire portfolio of completed energy projects. The most well-known is the "Energy-efficient Village", in which the village has been completely transferred to renewable energy sources (two solid fuel boilers for school and club heating and a heat pump for hospital heatinghave been built, $5 \mathrm{~km}$ of streets have been illuminated with solar panels). Moreover, the creation of an investment project for the construction of a $6 \mathrm{MW}$ solar power plant has been initiated, and it is now in the last stages of harmonization of projectdocuments. Active dialogue with potential investors is being held on the construction of a $25 \mathrm{MW}$ wind farm and a cogeneration unit that will extract gas from solid waste landfills. With the participation of the cluster, 3 energy cooperatives have been created: 2 for photovoltaic electricity production, and a cooperative for rapeseed cultivation and biodiesel production (Ihnatiev 2017).

What good do these projects serve? New orders for enterprises participating in the energy cluster, new innovations for the region's development, new megawatts of electric energy for the country's independence. And, of course, the cluster is a driver of local energy reforms, the results of which are reflected in national legislation. Therefore, Ukrainian clusters have a high chance of becoming drivers of local reforms: this is not an ambitious challenge, but a modern reality.

Sector clusters can turn into innovation hotspots, transforming innovation into a permanent process aimed at modernizing existing sectors and creating new ones based on the application of advancements in nanotechnology and biotechnology, hydrogen economy, quantum informatics and microelectronics. The cluster is an effective means of achieving competitiveness through informal integration of efforts by various institutions. Recognizing innovation as an endogenous factor for the progressive development of the national economy 
REVISTA DE LA UNIVERSIDAD DEL ZULIA. 3época. Año 11 N 31, 2020

Nataliia Lytvynenko et al.///Methods of calculating the efficiency of clusters ...97-118

DOI: http://dx.doi.org/10.46925//rdluz.31.08

and its components - localized economic systems, has determined the need for measures to stimulate the influence of subjects of innovative relations on behalf of the state.

In the past 27 years of Ukrainian independence, attempts to simply imitate successful development models of other countries proved to be ineffective. It is no secret that the "first world" states have long been thinking in terms that are completely different from ours. In order to integrate into the global economic space, we need to find and implement universal paradigms (Mlynskii 2018).

One of those paradigms is the cluster approach in economics, which has been successfully employed by many countries. This model of interaction has already proved its efficiency and is becoming more and more popular with each passing day.

Successful companies and simply rich people all over the world are increasingly awareof the importance of social responsibility and cooperation. Funds are being created, grants for the development of education and medicine are being issued. The values of the modern world are changing every day, and more and more people are realizing that one cannot be really happy when others are unhappy. Human capital and mutually beneficial cooperation are a basic element of success.

American economist Michael Porter studied the success of Japanese companies and drew attention to one remarkable feature: many of them operated together to help each other, thereby increasing their overall competitiveness, the quality of their products and consumer value. In the late 1990's he laid out his theory in depth in his book "The Competitive Advantage of Nations" (Mlynskii, 2018).

According to Michael Porter (2013, p. 16), "a cluster is a group of interconnected geographically proximate companies and related organizations (education, power, infrastructure), operating in certain areas".

A cluster can be viewed as an ecosystem, including members of different sizes and functions. At the same time, they are united by common vision and goals, their overall efficiency increases significantly, and synergy is achieved, when $1+1$ equals much more than 2 (Mlynskii, 2018).

There are many successful clusters in the world, and not necessarily very large. The "Diamond District" is a jewellery cluster on 47th Street in New York City. It is a small section of the street, only 300 meters, where each day $\$ 500$ million worth of goods are sold. There 
REVISTA DE LA UNIVERSIDAD DEL ZULIA. 3época. Año 11 N 31, 2020

Nataliia Lytvynenko et al.///Methods of calculating the efficiency of clusters ...97-118

DOI: http://dx.doi.org/10.46925//rdluz.31.08

are shops, museums, and over 2,500 world-famous jewellers. The most famous jewellery brands have their own representative offices in this district.

Examples of large clusters in the US include the Silicon Valley and Hollywood. In Europe, there are flower and product clusters in the Netherlands, the Bavarian car industry, the Italian shoe cluster, as well as many other well-known associations (Mlynskii 2018).

Cluster approach proves useful and beneficial for all parties involved. The government receives new jobs, investment and additional budget revenue. Science and education sectors receive commissions for new inventions, additional funding, an inflow of new students, more modern and high-quality educational programmes.

Meanwhile, the business environment gets enormous benefits: the opportunity to enter larger markets, a significant increase in the quality of products, a rapid development of new products, significant reduction research and innovation costs, which in turn helps reduce the negative impact on the environment.

Companies acquire access to state-of-the-art technology and profitable financial instruments; there is an opportunity for joint marketing research and advertising campaigns. The cluster's consumers have a higher level of trust and loyalty, and relations with authorities and the education sector are improved. A long-term consequence of all these changes is the overall development of the region and its infrastructure and the improvement of the quality of life of people.

Ukraine also has already successful examples (IT-cluster in Lviv), as well as fledgling clusters that have a significant potential for growth. World-famous wedding dresses sewn in Chernivtsi come to mind, or agrarian associations of farmers, seed and fertilizer suppliers, carriers, processors, and distributors. One of the vivid examples is the "strawberry village" of Lisky in the Kiliya district of the Odessa region, where about 2,000 people grow over 300 tons of strawberries annually. It is one of the largest suppliers of berries to Ukrainian markets, earning over 3 million UAH per year (Popelo 2014).

With the advent of new examples of effective interaction, slowly the patterns of thinking begin to shift. As it turns out, helping competitors is advantageous for many reasons. This is still a quite unusual approach for our business, but it will inevitably take root in our culture. It is also an opportunity for Ukraine to become a successful country of happy and wealthy people. 
REVISTA DE LA UNIVERSIDAD DEL ZULIA. 3 $3^{a}$ época. Año 11 N 31, 2020

Nataliia Lytvynenko et al.///Methods of calculating the efficiency of clusters ...97-118

DOI: http://dx.doi.org/10.46925//rdluz.31.08

Institutions that are part of inter-sectoral clusters, cooperate through vertical coordination (at the level of inter-sectoral division of labour) and through horizontal coordination. Therefore, a complex system has been developed that combines cooperation, competitiveness and industrial peculiarities. The proximity and effectiveness of this coordination are the results of the shaping factors of competitiveness. The cluster's operation depends directly on access to scientific knowledge and the latest technologies, as well as the ability to attract investment. Clusters with a well-developed intellectual and financial capital infrastructure show greater potential for capacity development and innovation of cluster enterprises.

Implementation of the cluster development policy stimulates the growth of business and innovation activities in the region, the improvement of the investment climate, the development of social, economic and information systems. As a result, this leads to an increase in entrepreneurial activity, an increase in investment resources and the restoration of all regional branches of the economy.

In the context of globalization and growing international competition, the Ukrainian economy depends largely on the ability of each region to compete successfully on the world market. Global changes, caused by political and economic factors, as well as by a rapid scientific and technological progress, require new approaches to the socio-economic development of Ukrainian regions. Increasing regional competitiveness becomes an economic priority for the regions of many countries, including Ukraine. One of the means of innovation in the economic development of the regions is the development of an industrial cluster approach.

However, for the dynamic development of cluster processes, it is necessary to improve the external and internal institutional environment of economic activity, in particular, create conditions for the implementation of inter-industry agreements between producers of various goods, suppliers of equipment and components, research and educational institutions, etc. (Dvorkind, 2004)

Of course, it is impossible to give a conclusive description of an industrial cluster. Certain difficulties in identifying and analyzing the activity of industrial clusters in the environment regional competition often represent their interregional boundaries, as well as 
REVISTA DE LA UNIVERSIDAD DEL ZULIA. 3época. Año 11 N 31, 2020

Nataliia Lytvynenko et al.///Methods of calculating the efficiency of clusters ...97-118

DOI: http://dx.doi.org/10.46925//rdluz.31.08

the domination of large integrated and diversified structures in the economies of different regions. This calls for developing concepts of industrial cluster creation.

It should be noted that due to globalization, the new role of clusters in the competitive struggle is becoming increasingly important, based on scientific knowledge and a dynamic economy.

For the development of regional industrial clusters, the following competitive advantages are required: the availability of natural resources, geographical location, accumulated industrial, scientific and educational potential, unique tourism and recreational potential. Yet at the same time, there are risks, problems, and threats: natural and climatic conditions of living and economic activity, unfavourable institutional environment, dependence on transport remoteness and the overall economic space (Horodova, 2012).

If the purpose of the cluster is to acquire a global reputation, attract specialized resources and access the global market, then it needs to attract the attention of financial institutions. The success of clusters strengthens and develops the economic environment in the region, promotes its economic growth, and therefore clusters have political significance for the authorities, primarily due to the fulfilment of social obligations to the society and the creation of favourable opportunities for economic and social development. Thus, industrial clustering can improve the image of the region, increase employment and welfare of people, replenish the budget and support the development of small business. Other market participants and investors join in on the activity in the region (Horodova, 2012).

In spite of the necessity of global cost reduction, during the development of industrial clusters, entrepreneurs can be focused on increasing living standards in the region. Firstly, growing companies always need skilled staff. Secondly, it is known that the company's reputation positively affects sales volumes. Finally, raising the standards living is an important factor in attracting talented professionals to the region.

The cluster approach, as shown by the experience of many countries, not only serves as a means of achieving objectives in the competitive struggle of regions, but also enhances innovation, is a powerful tool for stimulating entrepreneurial development, which may ultimately inspire an increase in employment, wages, budget contributions on various levels, increased efficiency and sustainability of the industry. 
REVISTA DE LA UNIVERSIDAD DEL ZULIA. 3 $3^{a}$ época. Año 11 N 31, 2020

Nataliia Lytvynenko et al.///Methods of calculating the efficiency of clusters ...97-118

DOI: http://dx.doi.org/10.46925//rdluz.31.08

The choice of a structural model for managing innovation processes in the region's economy is determined by the combination of endogenous and exogenous factors. Endogenous factors include the phase of the economic sector cycle (economic activity cycle), which determines the absolute and relative merits of the region. Moreover, the structural models of innovation process management differ in their key characteristics, which cause a negative synergistic result due to their non-critical combination or the adoption of formal features, which inevitably leads to the development of green field economy. In this regard, it is appropriate to identify those structural models of innovation process management based on the selection/creation of cluster entities and regional innovation systems as an object of monitoring action. The essential features of a cluster include:

- the geographical proximity of members of the integrated unit, which are located within the same region (municipality) and characterized by sectoral focus;

assorted membership in the association, represented by large, medium and small entrepreneurial structures, their integrated formations, research and educational institutions, public and local authorities, innovation infrastructure agencies, etc;

- a definite number of residents as a condition for creating localization and agglomeration effect;

- the purpose of the managing company is to increase the cluster's competitiveness;

- $\quad$ implementation of a joint project by cluster residents is a consequence of cluster initiatives implementation.

\section{Conclusion}

Thus, the formation of a cluster involves the procedure of preparing securities but does not restrict it, since it has a broader membership structure and is characterized by the distribution of costs, risks and profits throughout joint project implementation. However, a cluster cannot be equated with the association of economic agents due to its focus on the flow of projects, while lobbying for the interests of the residents is not the main goal of an alliance, aimed at finding internal development reserves.

The application of cluster approach is a natural step in economic development, and its propagation can be considered as the main feature of all highly developed economies. 
REVISTA DE LA UNIVERSIDAD DEL ZULIA. 3época. Año 11 N 31, 2020

Nataliia Lytvynenko et al.///Methods of calculating the efficiency of clusters ...97-118

DOI: http://dx.doi.org/10.46925//rdluz.31.08

A particular characteristic of a cluster is that its member organizations achieve a synergetic effect, which is expressed in increased competitiveness of the whole system compared with individual economic entities. The cluster mechanism of increasing competitiveness is based on the efficient combination of intra-cluster cooperation in the production process with internal competition within the industrial cluster. It is important to emphasize the network nature of interaction between its members since it is the horizontal integration that in this case contributes to the formation of a chain of diffusion of new knowledge, technologies and innovations.

A cluster is an effective means of achieving competitiveness through informal integration of efforts of various institutions. Recognizing innovation as an endogenous factor for the progressive development of the national economy and its elements- localized economic systems, has identified the need for measures to stimulate the influence of subjects of innovative relations on behalf of the state.

Conducting a cluster policy is premised on organizing the interaction between public and local authorities, businesses, and scientific and educational institutions in order to coordinate efforts to improve the innovation of manufacturing and services, which promotes mutual enhancement and improved efficiency.

Competitive clusters often have developed relations with similar clusters in other regions and countries. Stimulation of such international relations becomes an important direction of cluster policy and consists in developing cooperation between related clusters, creating and implementing development programmes. Clusters that are created in different regions of Ukraine do not, as a rule, belong to export-oriented high-tech scientific and manufacturing structures. These are mainly clusters in construction, consumer goods industry, wood-industry, and tourism, which cannot be identified as effective cluster cooperation structures.

In the long run, the development of hi-tech clusters in Ukraine will lead to a significant improvement in the economic situation in the country and will raise the level of Ukrainian business policy to a significantly higher level. At the moment, the construction of the cluster system is slow due to lack of investment cash inflows.

To conclude, a cluster contributes to the creation of a national innovation system in which the interaction between the generator of ideas and the consumer of those ideas takes 
REVISTA DE LA UNIVERSIDAD DEL ZULIA. 3época. Año 11 N 31, 2020

Nataliia Lytvynenko et al.///Methods of calculating the efficiency of clusters ...97-118

DOI: http://dx.doi.org/10.46925//rdluz.31.08

place. The main distinguishing features of an innovation cluster are territorial limitations, close horizontal and vertical ties between legally independent organizations in a particular field of activity. Moreover, a cluster can be viewed as one of the main tools of economic analysis that can reveal the innovative potential of a region, sector or the country as a whole at regional and macro levels.

\section{References}

Boyko, Tetiana (2011). "Methodological approach to evaluating organizational and economic mechanism's effectiveness of the entrepreneurial cluster's management regulation" In: Bulletin of Zaporizhia National University, Num. 1 (9), pp. 15 - 21.

Danilov, S., Lukyanova, M., \& Aryabkina, I. (2020). Methodological and practical aspects of pedagogical innovation logistics application in the regional educational holding. Amazonia Investiga, 9(28), 30-41. https://doi.org/10.34069/AI/2020.28.04.4

Dvorkind, Anton (2004). Clustering as a promising direction of economic development of the region (On the example of the Samara region). PhD. Samara State Economic Academy.

Gorbunov, A., Kolyadin, A., Burnyasheva, L., Gazgireeva, L., \& Kosenko, O. (2018). Tourist and recreational clusters as organizational and economic mechanism of control of formation and development of innovative capacity of the North Caucasus Federal District. Amazonia Investiga, $\quad 7(17), \quad 60-71.6$ Retrieved https://amazoniainvestiga.info/index.php/amazonia/article/view/326

Horodova, Iryna (2012). "Prospects for the development of industrial clusters in the competitiveness of regions" In: Economics and environmental management, Num. 1, pp. 152 -155 .

Ihnatiev, Stanislav (2017). "Who needs clusters in Ukraine?" In: HB Business. Available online. In: https://nv.ua/ukr/biz/experts/komu-potribni-klasteri-v-ukrajini-1275343.html. Date of consultation: 25/05/2020.

Kiryk, Mykola (2014). "Clustering in the strategy of innovative development of foreign countries" In Scientific Bulletin of Kherson State University, Series "Economic sciences", Issue $6(1)$, pp. $78-83$.

Lienchuk, Yelena and Vlaskin, Herman (2010). "Cluster approach in the strategy of innovative development of foreign countries" In: Studies on Russian Economic Development, Issue 5, $38-51$.

Mlynskii, Viacheslav (2018). Cluster approach in Economy. Business Zavarnik Convergent media. Available online. In: http://zavarnik.biz/klasternyj-podxod-v-ekonomike. Date of consultation: 25/05/2020. 
REVISTA DE LA UNIVERSIDAD DEL ZULIA. $3^{a}$ época. Año 11 N 31, 2020

Nataliia Lytvynenko et al.///Methods of calculating the efficiency of clusters ...97-118

DOI: http://dx.doi.org/10.46925//rdluz.31.08

Novikov, S., \& Prosvirina, N. (2019). Clusters classification in the modern innovation economy. Amazonia Investiga, 8 (19), 620-630. Retrieved from https://amazoniainvestiga.info/index.php/amazonia/article/view/277

Patil, Channamma and Baidari, Iswar. 2019. "Estimating the Optimal Number of Clusters $k$ in a Dataset Using Data Depth" In: Data Science and Engineering, Num. 4, pp. 132-140, doi: https://doi.org/10.1007/s41019-019-0091-y

Popelo, Olha (2014). "Entrepreneurial clusters as an innovative dominant of regional economy modernization" In: Regional Economy, Num. 2, pp. 95 - 105.

Popov, Havryil (1976). The assessment of management workers. Moskow: Moskow worker.

Porter, Michael E. (2013). "Location, Competition and Economic Development: Local Clusters in a Global Economy" In: Economic Development Quarterly 14, Num. 1, pp. 15-34.

Prokhorova, Viktoriya V.; Artemova, Elena I.; Miroshnichenko, Marina B.; Rafaelovna, Avanesova Rita; Mausurovna, Chazhaeva Maynat (2020). Cluster Technology as a basis for the competitive development of industries in Russia, Revista de la Universidad del Zulia, 11 (29), 265-275, DOI: http://dx.doi.org/10.46925//rdluz.29.17

Razminienè, Kristina, Tvaronaviciene, Manuela and Zemlickienè, Vaidan (2016). "Evaluation of cluster efficiency measurement tool" In: Terra economicus, Num. 14, pp. 101111, doi: 10.18522/2073-6606-2016-14-3-101-111.

Schwab, Klaus (2014). The Global Competitiveness Report 2014 - 2015. World Economic Forum. Available online. In: http://www.weforum.org/reports/globalcompetitivenessreport-2014-2015. Date of consultation: 25/05/2020.

Tapas Kanungo, Mount, David M., Netanyahu, Nathan S., Piatko, Christine D., Silverman, Ruth and Wu, Angela Y. (2002). "An efficient k-means clustering algorithm: analysis and implementation" In: IEEE Transactions on Pattern Analysis and Machine Intelligence, Vol. 24, Num. 7, pp. 881-892, doi: 10.1109/TPAMI.2002.1017616.

Vorozhbit, O., Titova, N., Kuzmicheva, I., \& Borovitskaya, M. (2018). Development of competitive advantage evaluation technique for industrial clusters on the basis of $\mathrm{m}$. porter's national competitiveness model "Rhombus\&quot; transformation. Amazonia Investiga, 7(13), 308-321. Retrieved from https:/amazoniainvestiga.info/index.php/amazonia/article/view/562 